\title{
Identifying the Use of Online Resources in Doing Self-Corrections: A Study of Indonesian Student Translators
}

\author{
Rudy Sofyan ${ }^{1}$, Roswita Silalahi ${ }^{1}$, Eddy Setia ${ }^{1}$, Bahren Umar Siregar ${ }^{2}$ \\ ${ }^{1}$ Linguistics Department, University of Sumatera Utara, Medan, Indonesia \\ ${ }^{2}$ English Applied Linguistics Department, University of Atmajaya, Jakarta, Indonesia
}

Email address:

rudy_sofyan@yahoo.com (R. Sofyan),roswita_silalahi@yahoo.com (R. Silalahi), eddy12457@yahoo.com (E. Setia), bahren.siregar@gmail.com (B. U. Siregar)

\section{To cite this article:}

Rudy Sofyan, Roswita Silalahi, Eddy Setia, Bahren Umar Siregar. Identifying the Use of Online Resources in Doing Self-Corrections: A Study of Indonesian Student Translators. International Journal of Applied Linguistics and Translation. Vol. 2, No. 2, 2016 , pp. 15-19. doi: $10.11648 /$ j.ijalt.20160202.11

Received: April 7, 2016; Accepted: June 16, 2016; Published: July 5, 2016

\begin{abstract}
This research is aimed at investigating the use of online resources in doing self-corrections. To achieve this objective, this research uses triangulation method by combining keyboard logging program (Translog-II), screen recording tools (Camtasia) and retrospective questions to collect the data. This research belongs to a qualitative research employing an exploratory case study as a method. The researcher views external processes - especially in terms of using online resources in doing self-corrections - while translating an English text into an Indonesian text as the central phenomenon requiring exploration and understanding. The participants are student translators - the students of Master Degree Program of Linguistics Department majoring translation studies at the University of Sumatera Utara (USU) without any professional experience on translation. The participants have a paper based TOEFL score of more than 475, UKBI score of more than 550, typing speed of more than above $20 \mathrm{wpm}$ (words per minute) with more than $90 \%$ of accuracy. The findings show the student translators' preference to using Google translate while doing self-correction, their dependence on translation machines and online dictionaries, and their low capability in managing online resources.
\end{abstract}

Keywords: Online Resources, Self-Correction, Translation Process

\section{Introduction}

Translation process research (TPR) describes the processes taking place in the translator's mind while translating a text. Schubert (2009: 19) divides translation processes into internal process and external process. The former refers to the mental activity involved in carrying out the translation work with all its steps and decisions which are not open to direct observation. Therefore, mental processes, as the term used by Göpferich (2008: 1), are often referred to as 'the translator's black box' (Toury, 1982: 25). Meanwhile, the latter refers to everything in the translation process which can be observed by another person.

One of the observable processes taking place while translating is self-correction (see Malkiel, 2009) or selfrevision (see Carl et al., 2010; Carl and Kay, 2011; Mossop,
2001). Self-correction is a personal correction during the translation process covering deleting words, substituting words, respelling, adjusting the meaning, etc. Self-correction or self-revision in translation is a kind of revision taking place in translation process. Following Robert (2008: 5), the term 'revision' refers either to the process of revising one's own translation, or to the process of revising others' translation. Therefore, self-correction or self-revision in translation process can be defined as a process of giving correction or revision done by the translator him/herself while translating a certain text.

The term self-correction was used by some researchers in their study including Mizón and Diéguez (1996) and Malkiel (2009), while the term self-revision was used by some researchers including Mossop (2001) and Carl and Kay (2011). Malkiel (2009: 150) defines self-corrections as 
instances in which the writer or translator makes an addition, a deletion, or a change to the target text. The core idea of self-correction is making a change to the text done by the translator him/herself while doing translation. She added that a self-correction is not necessarily a change from incorrect to correct, but can involve a subtle alteration, such as 'a book' to 'the book'. In addition, Carl and Kay (2011: 9) use the term 'self-revision' to refer to one of the stages of translation process in which some or all of the translated text is reread, retyped, and corrected: the sentences are possibly reformulated or rearranged for the purpose of a better understanding of the contents of the Source Text (ST) that has been acquired by the time this stage is reached.

While doing self-correction, the translators need a help for the purpose of translation improvement. Such help can be either printed resources - dictionaries, books, etc. - or online resources or both. While observing the students do their translation tasks in the classroom, the researcher found some of them taking pauses for not doing anything; neither did they write nor did they open dictionaries or other reference books. In other words, some students only relied on their previous knowledge to solve the problem of their translation tasks. They were thinking while translating thus doing no physical activity. Meanwhile, others were busy reading dictionaries and reference books to help them solve their translation problems. Interestingly, when they submitted their tasks, the researcher found that the students who use various resources could produce better quality of translations.

As technology develops, the use of online resources is more preferable for its efficiency, effectiveness, and practicality. Byrne (2007: 33) argued that the internet has a much more profound impact on translation in terms of the way it is carried out and the tools that are used as well as the industry that has developed around it. The internet is an online service provider through which translators can access various services assisting them in the translation process. In addition, in her research, Kourouni (2012) found that the management of online resources helped the translators translate their texts more quickly.

Using online resources in doing self-correction is precisely the focus of this study. Specifically, this research is aimed at investigating the use of online resources in doing selfcorrections including the reasons why the student translators use certain online resources in doing self-corrections when translating the text. The result of this study gives contribution to a better management of online resources in a translation process, especially in doing self-corrections. However, this research does not examine whether the use of online resources in doing self-corrections contributes to the quality of the translated texts.

\section{Methodology}

In accordance with the research problems, this research belongs to a qualitative research for its purpose of exploring a problem and a detailed understanding of a central phenomenon development (Creswell, 2011: 16). The researcher viewed the participants' online activities in doing self-corrections during translating a text from English into Bahasa Indonesia as the central phenomenon requiring exploration and understanding. Considering the nature of the target phenomenon (i.e., the use of online resources in doing self-correction), the researcher followed the advice of Strauss and Corbin (1998: 11) who explained that qualitative methods can be used to obtain the intricate details about phenomena such as feelings, thought processes, and emotions that are difficult to extract or learn about through more conventional methods.

The participants are 3 students of Master Degree Program of Linguistics Department majoring translation studies (student-translators) at the University of Sumatera Utara. They are all native speakers of Bahasa Indonesia and share a relatively homogeneous profile. Besides, they have no professional experience on translation. They have an average proficiency of English (L2) with a paper-based TOEFL score of more than 475, have an excellent proficiency of Bahasa Indonesia with an UKBI (test of Bahasa Indonesia proficiency) score of more than 550, have a good typing skill at above $20 \mathrm{wpm}$ (words per minute) with more than $90 \%$ of accuracy. They were asked to translate two texts from English language to Indonesian language. The two texts entitled 'Apple vs. Google Is the Most Important Battle in Tech' and 'The Wholesome Hidden Message of Gangnam Style' were downloaded from Online Time Magazine.

All of the keyboard activities in doing self-corrections were recorded by using Translog. In addition, Camtasia Studio 8, a screen recording tool, was used to record both online and offline activities undertaken by the participants in doing self-corrections. Then, they were asked to fill in the questionnaire to find the reasons of employing certain online resources in self-correcting their translated texts.

\section{Findings and Discussions}

The findings show that the self-corrections were done simultaneously with the other stages of translation process. In other words, the student translators did self-corrections before the texts were completely transferred to the target language (TL). Following Jakobsen (2002), Mossop (2001), and Yamada (2009), translation process, in a broader sense, is a series of translating activities involving three phases: pre-drafting (startup), drafting (writing phase), and post-drafting (revision). However, denying an order of a series of translating activities does not mean a failure in translation; instead, it is one of the methods in doing self-corrections which Kourouni (2012: 195) called multidirectional or non-linear translation method. In this method, the translators leave the title for the end, translate a few lines and then start again from the beginning, or jump to a second paragraph, and so forth.

Kourouni's idea follows Asadi and Séguinot (2005) who identified two different approaches in the distribution of selfrevision phases throughout the translation activity. In the first approach, writing, researching and revising tasks take place during all three phases of pre-drafting, drafting and post- 
drafting. Meanwhile, in the second approach, self-revision is done once the whole text has been already translated.

A variety of online resources were used by the student translators in doing self-correction, searching for the most helpful sites in solving the problems in translation such as terminology, vocabulary, etc. They visited a number of websites that they were familiar with and used to consult them in their classroom translation projects. Therefore, it is quite reasonable when they did not try new sites of online resources for being uncomfortable of using them for whatever reason. Moreover, one of the student translators even visited very few numbers of websites because of her low practice of using online resources in doing self-corrections. The online resources used or the websites visited were beritagar.com, wordpress.com, freakonomicsindonesia.com, merdeka.com, wikipedia.org, ciricara.com, dictionary.reference.com, blogspot.com, gopego.com/news, reopan.com, szaktudas.com, m.live.viva.co.id/news, and thefreedictionary.com. In general, the screen reveals four broad categories of online resources used by the student translators in doing self-corrections, they are encyclopedias, free machine translation services, online dictionaries, and online search engines.

The student translators used online resources for various self-correction purposes including self-correcting the terminology, vocabulary, structure, and social acceptability. The screen recorded that Google Translate (translate.google.com) is the site most frequently visited by the student translators while doing self-correction. In terms of selfcorrecting a single word, Google Translate provides several possible words in the target language (TL) to one of which the word to be-corrected in the source text (ST) can be correctly transferred. Google Translate is a dictionary-like with more translation applications than other common online dictionaries, usually providing word-by-word translations, for its facility of transferring not only words but also phrases, clauses, even texts from the source language (SL) to the target language (TL). In addition to Google Translate, there are, actually, many other online resources they can visit to help them in the selfcorrection process such as imtranslator.net, conveythis.com, translated.net, translation2.paralink.com, bing.com/translator/, reverso.net/text_translation.aspx? lang=EN, proz.com., kwintessential.co.uk/free-online-translation-dictionary.html., freetranslation.com., babelfish.altavista.com, thefreedictionary.com., etc.

Their preference in using Google Translate is due to the fact that Google Translate always allows anybody to improve the translated text it provides; therefore, gradually its translation becomes better and better. Moreover, as the texts translated by the student translators are news, Google Translate works better for translating news (Och, 2006). Nevertheless, relying completely on Google Translate in translating the text is, certainly, not a good choice. Kamalie (2011: 71) noted the incapability of Google Translate in providing good collocation/idiom and language style in the TL. He finally concluded that until today Google Translate has not been successful to translate a number of words and phrases perfectly.
In terms of self-correcting the terminology, the online resources used by the student translators are Google Search, wikipedia, Google Translate, dictionary-reference.com., and idiomatic online dictionary. The Google Search space was used to write the key words containing the terminology they needed to self-correct. For example, in self-correcting the translation of the terminology 'Gangnam Style' in text 2, they wrote 'demam Gangnam Style' in the search space and found the article "Demam Psy, Gavin MJ Gangnam Style Bareng Fans" on the viva.co.id page. The use of 'demam (fever)' in the keywords indicates the search of Indonesian texts for the purpose of finding the equivalent term of the "Gangnam Style" in the Indonesian context. Through the exploration to various sites providing the use of Gangnam Style term in Indonesian texts, the screen recorded that the term "Gangnam Style" is not changed when translated into Bahasa Indonesia.

In addition, Google Translate and dictionary.reference.com were also used by the student translators to translate the terminology from the SL to the TL. However, the use of these sites has weaknesses because they offer only a translation of the term without considering whether the term is socially acceptable in Indonesian texts. Another online resource used in self-correcting the terminology is idiomatic dictionary. One of the student translators translated the term 'locked horns' in SL with 'mengunci (to lock) dan (and) melampaui (to exceed)' in the TL. During self-correction, she visited the site of idiom.thefreedictionary.com and found its equivalence of 'memperebutkan (to compete for)' in the TL. The meaning provided by the site was then kept in her translation. Nevertheless, idiomatic dictionary works only for idiomatic expression translation; meanwhile, not all terminology used in the text is idiomatic.

Furthermore, in terms of self-correcting the vocabulary, the online resources used by the student translators are Google Search and Google Translate. These two sites are considered helpful for their facility in providing the intended vocabulary and its uses in the Indonesian texts. Google Translate provides several possible words in TL allowing the student translators to choose the best words accommodating the translation of the vocabulary in the SL. Meanwhile, Google Search is used to check the use of vocabulary in the Indonesian texts.

In self-correcting the structure of their translated texts, the student translators visited Google Search site on which they searched Indonesian articles to self-correct their sentence structure; but one of them did not use any online resources in correcting her sentence structure. The self-correction of sentence structure is mostly related to the role and the function of a particular word or phrase in a sentence. Therefore, the screen recorded that they frequently used Google Search and wrote the word 'define' followed by a certain word or phrase. For example, to search for the role and the function of the phrase 'locked horns', they wrote 'define locked horns' and the site guided them to other online resources defining its role and function.

In relation to the social acceptability of their translated texts, the student translators visited Google Search to find several articles in the TL to make sure whether the terminology, the 
vocabulary, and the structure used in their translation are socially acceptable. Acceptability plays a very important role in the quality of the translation product because it also leads to the readability of the text. While self-correcting their translation for the purpose of social acceptability, the student translators read some Indonesian articles and materials found through Google Search. For example, when translating the clause 'The song is catchy enough', they firstly translated it 'Lagunya cukup memikat' and self-corrected the word 'memikat' with 'menarik', both refer to the word 'catchy' after reading the online Indonesian article entitled 'Pesan di balik Lagu Gangnam Style' on beritagar.com/p/pesan_dibalik_lagu_gangnam_style. The word 'memikat' in Indonesian language is socially accepted as a verb, not as an adjective, even though it can represent the meaning contained in the word 'catchy'.

These findings indicate the student translators' low capability in online resources management. The Internet is a limitless cyberspace in which they can freely surf and browse everything they needed in self-correcting their translated texts without having to be limited on a certain few websites. Less frequently involved in translation projects, limited knowledge on online resources applicable in the translation process, and relying on a particular online resources are the causes leading to their low capability in online resources management.

Nevertheless, referring to the data from the questionnaire, all of the student translators are really aware of the huge benefit of using online resources in translation. They even admitted that they could not work well in translation, especially in doing self-correction, without the assistance of online resources. Getting some references regarding the ideas discussed in the ST helps them in self-correcting some terminologies in the target text (TT). In addition, some unfamiliar words can be easily translated to the TL through the assistance of translation machine and/ or online dictionaries.

Furthermore, in relation to using less variety of online resources, they said that quality always defeats quantity; in other words, using two to three websites facilitating good translation quality is better than using hundreds of websites leading to confusing translation process. In addition to confusing states, using too many online resources also takes time in completing the translation tasks.

Their arguments need to be clarified since the use of many online resources does not result in too much time consumption. The problem does not lie on the time consumption, but on the online resources management. Kourouni (2012: 201) reported that more than half of her research participants $(60 \%)$ stated that they had enough time to perform the internet searches they wished to make. This finding emphasizes the incomparability of using various online resources to time consumption. This is, purely, a matter of management supported by a good knowledge on using online resources in translation because spending too much time in searching the applicable online resources indicates low knowledge in managing online resources.

Quality is, undeniably, the purpose of every translation, and this is the main reason why translators spend time for self- correction. Nevertheless, relying only on translation machine and online dictionaries may lead to misleading translation, taking the translated text far away from the expected quality. Translation is a matter of finding equivalent meaning of the text both in SL and TL (Baker, 1998; Catford, 1965; Larson, 1984; Panou, 2013); meanwhile, translation machine and online dictionaries usually work on language transfer. Therefore, using translation machine in doing self-correction should be accompanied by other online resources providing equivalent meaning of the translated text.

\section{Conclusions}

As the findings reveal that student translator with better ability in online resource management produces better quality of translation, using online resourses in doing self-corrections is very beneficial. They can work faster with a good quality of the translated text if they are able to manage online resources. The most important point to be delivered in relation to online resource management is the ability to choose the right website for the right translation problem. All of the information in websites can be useless if translators do not know what they want to find out in those websites.

However, the student translators performed low capability in managing online resources. Their focus was more on translation machine and online dictionaries, but less attention to the factor of social accebtability. Online resources lead to good performance on self-correction when appropriately managed; but, if badly managed, they will disrupt the translated text. Therefore, using online resources in doing selfcorrection must be taken into account in giving courses to the student translators in order that they can get its best benefit.

\section{References}

[1] Asadi, P. \& C. Séguinot. 2005. "Shortcuts, Strategies and General Patterns in a Process Study of Nine Professionals". Meta, 50(2): 522-547.

[2] Baker, M. 1998. The Routledge Encyclopedia of Translation Studies. London: Routledge

[3] Byrne, J. 2007. "Translation and the Internet: Changing the Face of an Industry". In Ian Kemble (ed.). Translation Technologies \& Culture. Portsmouth: University of Portsmouth, 23-34.

[4] Carl, M., M. Kay \& K. T. H. Jensen. 2010. "Long Distance Revisions in Drafting and Post Editing". In CICLing-2010, Iasi, Romania.

[5] Carl, M., \& M. Kay. 2011. "Gazing and Typing Activities during Translation: A Comparative Study of Translation Units of Professional and Student Translators". Meta: Translators' Journal, 56(4), 952-975.

[6] Catford, J. C. 1965. A Linguistic Theory of Translation: An Essay in Applied Linguistics. London: Oxford University Press.

[7] Creswell, J. W. 2011. Educational Research: Planning, Conducting, and Evaluating Quantitative and Qualitative Research. Fourth Edition. Boston: Pearson. 
[8] Göpferich, S. 2008. Translationsprozessforschung: Stand, Methoden, Perspektiven. Tübingen: Narr.

[9] Jakobsen, A. 2002. "Logging target text production with Translog". In G. Hansen (Ed.). Probing the Process in Translation: Methods and Results. Samfundslitteratur: Copenhagen, 9-20.

[10] Kamalie, S. 2011. "Google Terjemahan: Apa dan Bagaimana?". Ronshu UAI Journal of Japanese Studies, 5872 .

[11] Kourouni, K. 2012. "Translating Under Time Constraints in an Undergraduate Context: A Study of Students' Products, Processes and Learning Styles". Doctoral Thesis. Tarragona: Universitat Rovira I Virgili.

[12] Larson, M. 1984. Meaning-based Translation: A Guide to Cross-language Equivalence. New York: University Press of America.

[13] Malkiel, B. 2009. "From Ántonia to My Ántonia: Tracking self-corrections with Translog". In Susanne Göpferich, Arnt Lykke \& Jakobsen Inger M. Mees (Eds.), Behind the Mind: Methods, Models and Results in Translation Process Research. Copenhagen: Samfundslitteratur Press, 149-166.

[14] Mizón, M. I. \& M. I. Diéguez. 1996. "Self Correction in Translation Courses: a Methodological Tool". Meta, 41(1), 7583.
[15] Mossop, B. 2001. Revising and Editing for Translators. Manchester, UK; Northampton, MA: St. Jerome.

[16] Och, F. 2006. "Statistical Machine Translation Live". Downloaded from http://googleresearch.blogspot.com/2006/04/statisticalmachine-translation-live.html on June 15, 2014.

[17] Panou, D. 2013. "Equivalence in Translation Theories: A Critical Evaluation". Theory and Practice in Language Studies. Vol. 3(1), 1-6.

[18] Robert, I. 2008. "Translation Revision Procedures: An Explorative Study". In P. Boulogne (ed.). Translation and Its Others. Selected Papers of the CETRA Research Seminar in Translation Studies.

[19] Schubert, K. 2009. "Positioning Translation in Technical Communication Studies". The Journal of Specialised Translation, (11): 17-30.

[20] Strauss, A., \& J. Corbin. 1998. Basics of Qualitative Research: Techniques and Procedures for Developing Grounded Theory. Second Edition. Thousand Oaks, CA: Sage.

[21] Toury, G. 1982. "A Rationale for Descriptive Translation Studies”. Dispositio, 7(20): 23-39.

[22] Yamada, M. 2009. "A Study of the Translation Process through Translators' Interim Products". Interpreting and Translation Studies, (9): 159-176. 